\title{
Assessment of the Knowledge And Awareness of Menopausal Coping Strategies Among Women In Umuowa Community, Orlu Local Government Area, Imo State Nigeria.
}

\author{
Ohamaeme Moses $C^{1}$, Egwurugwu Jude $N^{2}$, Ezeala Galina $C^{3}$, \\ Ohamaeme Chinyere R ${ }^{4}$. Ebuenyi M.C ${ }^{5}$. \\ ${ }^{I}$ Department Of Community Medicine, Nnamdi Azikiwe University Teaching Hospital, Nnewi. \\ ${ }^{2}$ Department Of Human Physiology, College Of Medicine Imo State University, Owerri. \\ ${ }^{3}$ Department Of Nursing, Madonna University Teaching Hospital, Elele. \\ ${ }^{4}$ Department Of Education Sociology, Imo State University, Owerri. \\ ${ }^{5}$ Health Promotion Unit, Adolescent Rights And Care Foundation, Owerri, Nigeria.
}

\begin{abstract}
We assessed the knowledge and awareness of menopausal coping strategies among women in Umuowa community, and we specifically looked at diet, exercise, estrogen replacement and their overall level of knowledge to these coping strategies. Two hundred and thirty-two respondents who had experienced menopausal symptoms responded to a questionnaire. Data collected was presented in tables and described with frequency distributions and percentages. Results showed that the level of awareness of diet, exercise and estrogen replacement as coping strategies for menopause were low. Also the overall knowledge about these strategies was also low among the women. Consequent upon these, we recommend enlightenment campaign and education of women about these strategies to cope with menopause while suggesting further studies on the subject matter.
\end{abstract}

Keywords: Menopause, Knowledge, awareness, coping strategies.

\section{Introduction}

The Knowledge of the biological clock and the circadian rhythm of women may still be very novel among rural dwellers and therefore calls for proper education and counselling, so as to maintain good health and well-being. The woman has a life that spans through puberty, menarche, procreation, and meno-pause. These stages of life impact on their health positively and negatively (Imagie 2002). Menopause is a term used to describe a woman's' final menstrual period, which occurs when the ovaries have stopped producing hormones that drive the menstrual cycle (Andrea, 2014). Menopause means the cessation of the ovarian and uterine cycle of growth, death, and repair. It's occurrence varies with different women, however it is rare for menstruation to persist in normal cycle much beyond the age of 50 years. Between the ages of 45 and 55years, menstrual cycle first becomes irregular and then ceases. This process is actually not the reverse of menarche because the secretion of gonadotropin continues and is greatly increased due to the loss of interest in sexual activity (Masters, 2001 \& Wood, 2001). The mechanism and cause of menopause is not known, however, the phenomenon shows an array of interplay between hormones and nervous system on one hand, and the interaction between the cultural and psychological factors on the other (Michinlay, 2004). Several factors have been known to influence menopause among women, such as inherited disposition, illness, medication, radiation of the pelvis, smoking, disease of ovaries, poor nutritional status, stress, oophorectomy, excessive alcohol consumption, hormonal imbalances, ovarian malfunction and many others(Onuzulike, 2007).

While menopause is a natural process, it is pertinent to state that variability in symptoms occurs from few to multiple physical and psychological symptoms such as irregular menstrual period, hot flushes, and night sweat (Ewuzie, 2007). Other symptoms include vaginal changes such as disappearance of vaginal rugae, and vaginal dryness which could lead to painful coitus, hence decreased libido in some women at this stage (Nnodum, 2004). There is also urine incontinence, skin dryness, body and joint pains, dyspepsia, psychological upset that may arise from the woman`s environment, irritability, depression, anxiety, insomnia, and osteoporosis (Onuzulike, 2004 and Ewuzie, 2007). All healthy women will transit from puberty to pre-menopause and finally menopause to post-menopausal state (Grady, 2006, Soules, 2005). Ande et al (2011) also stated that while menopause was considered a normal event in $97.4 \%$ of women, another $2.6 \%$ believed it was a disease condition. Also Nkwo and Onah (2008) stated that some societal privileges enjoyed by menopausal women in some communities actually helped to modulate the symptoms of menopause though not totally eliminating them. Several strategies have been employed to cope with menopause and these are under two broad headings of hormonal and non-hormonal therapy (Ewuzie, 2007 and Nnodum, 2004). The hormonal therapy requires physician's consultation as it is not suitable for every woman. It involves the use of hormone replacement 
therapy such as pills, patches, implants, vaginal creams, and sometimes testosterone to increase sexual desire. The non-hormonal therapies include exercise, diet, acupuncture, herbal treatment, homeopathy, and counselling. Oshinowo (2003) also opined that conventional management options for menopause include hormone replacement therapy, nutritional supplement and adequate diet, as well as sex therapy. The author further stressed the need for self image improvement, marital and sexual satisfaction as supportive strategies to cope with menopause. Having mentioned the above coping strategies, Santoro et al (2015) further stated that menopausal women need support, counselling and education during menopause and were the need arises, hormone replacement therapy could be employed for hot flushes, while systemically administered selective estrogen receptor modulators e.g Ospemifene could be utilized for Vaginal dryness/ atrophy. They need to be encouraged, reassured, loved, and cared for, hence in situations like sleep disturbances appropriate clinical evaluation need to be done and managed accordingly while in case of depressive mood, drugs like citalopram and escitalopram that has less metabolic interactions could be utilized. Yazdkhasti et al (2015) further buttressed the fact that health education, exercise, healthy diet, stress management, and preventing diseases` like osteoporosis also help women to cope with menopause.

This study therefore, assessed the level of awareness of menopausal coping strategies among women in Umuowa rural community of Imo State, Nigeria.

\section{Research Design}

\section{Methodology}

Descriptive survey design was used to assess the awareness of menopausal coping strategies among women in Umuowa community.

\section{Study Area}

Umuowa Community is in Orlu Local Government Area, and made up of 13 villages which includes Umuogu, Umuojima, Ezikeagu, Oduicheku, Umuezukwe, Umudim, Okwuetiti, Umudike, Umuokwaraebika, Okwu, Umudaduru, Ejemekwuru, and Uhu. It is headed by a traditional ruler and has a total population of 10,528 according to 2006 National population census and 2,800 were menopausal women from the community. Inclusion criteria was women aged between 45-55 years experiencing peri-menopausal and post-menopausal symptoms, while those women who are mentally ill or severely ill will be excluded from the study.

\section{Sample Size}

A total of 280 women aged 45-55years were randomly selected from 7 villages out of the 13 villages as stated by Ejifugha (2005) that when a population is in few thousand, ten percent $(10 \%)$ of the population could be used for generalization.

\section{Sampling Technique}

Multi-stage sampling technique was utilized for this study

Stage 1: All peri-menopausal women aged 45-55 years clustered into the thirteen representing villages in Umuowa. Of the 13 villages, simple random sampling technique by balloting was used to select seven villages. Stage 2: All kindred's in the seven villages were listed out. Two kindred`s were selected from each village by simple random sampling.

Stage 3: Non-probability sequential recruitment was employed to select the first 20 women that attended the kindred monthly meeting in August 2010.

\begin{tabular}{|c|c|c|c|c|}
\hline & Villages in Umuowa & Villages drawn & $\begin{array}{l}\text { No. of Kindred`s } \\
\text { chosen }\end{array}$ & $\begin{array}{l}\text { Respondents per } \\
\text { kindred. }\end{array}$ \\
\hline 1 & Umuogu & $\mathrm{x}$ & 2 & $20 \times 2=40$ \\
\hline 2 & Umuojimma & & & \\
\hline 3 & Ezikeagwu & $\mathrm{X}$ & 2 & $20 \times 2=40$ \\
\hline 4 & Oducheku & & & \\
\hline 5 & Umuezukwe & $\mathrm{X}$ & 2 & $20 \times 2=40$ \\
\hline 6 & Umudim & & & \\
\hline 7 & Umudike & $\mathrm{X}$ & 2 & $20 \times 2=40$ \\
\hline 8 & Umuokwaraebika & & & \\
\hline 9 & Okwu & $\mathrm{X}$ & 2 & $20 \times 2=40$ \\
\hline 10 & Umudaduru & & & \\
\hline 11 & Ejemekwuru & $\mathrm{X}$ & 2 & $20 \times 2=40$ \\
\hline 12 & Uhu & & & \\
\hline \multirow[t]{2}{*}{13} & Okwuetiti & $\mathrm{x}$ & 2 & $20 \times 2=40$ \\
\hline & Total & & 14 & 280 \\
\hline & & & & \\
\hline
\end{tabular}




\section{Summary table of villages drawn and respondents per kindred. Instrument for Data Collection.}

A semi- structured interviewer-administered questionnaire developed by the research team based on relevant literature was used for this study. The questionnaire consisted of Socio-demographic section, questions on exercises, diet, and estrogen replacement therapy. The respondents ticked their answers on a four point scale of Strongly Disagree(SD), Disagree(D), Agree(A), and Strongly Agree(SA).

\section{Method of Data Collection and Analysis.}

A formal letter of introduction was presented to the Eze of the village after advocacy on the need to conduct the study. Similar letter was presented to the Women Leader in Umuowa community to enlighten the women and allow for the study. Visit was made on the scheduled meeting day and the research team administered the 280 questionnaire. Of the 280 copies of questionnaires distributed, 18 copies were not properly filled, 30 copies were lost while 232 copies were tallied and used for data analysis. Data collected were analysed using descriptive statistics of frequency and percentages.

\section{Ethical Approval}

Ethical approval was sort and obtained from Madonna University Teaching Hospital, ethical committee, River state, Nigeria while each respondent signed the consent form attached to the questionnaire.

\section{Results Results}

Table 1a: Frequency distribution of respondents ages

\begin{tabular}{|l|l|l|}
\hline Age (years) & Frequency (f) & Percentage (\%) \\
\hline $40-50$ & 88 & 37.9 \\
\hline$\geq 51$ & 144 & 62.1 \\
\hline Total & $\mathbf{2 3 2}$ & $\mathbf{1 0 0}$ \\
\hline
\end{tabular}

Table 1 shows the frequency distribution of respondents' age. About 88 (37.9\%) are within the ages of 40-50 years, while $144(62.1 \%)$ are 51 years and above. The mean age of the respondents is $\mathbf{5 0 . 4 \pm 0 . 3 8}$.

Table 2: Summary Of Respondents` Level Of Knowledge About Menopausal Coping Strategies.

\begin{tabular}{|l|l|l|}
\hline Menopausal coping strategy & High & Low \\
\hline Exercise & $98(42 \%)$ & $134(58 \%)$ \\
\hline Adequate diet & $97(42 \%)$ & $135(58 \%)$ \\
\hline Estrogen replacement therapy & $88(38 \%)$ & $144((62 \%)$ \\
\hline
\end{tabular}

Table 2: Shows that the awareness of exercise, adequate diet, and hormone replacement therapy as menopausal coping strategies was low among rural women in Umuowa community

Table 3: Frequency distribution of respondents` level of education

\begin{tabular}{|l|l|l|}
\hline Level of education & Frequency $(\boldsymbol{f})$ & Percentage (\%) \\
\hline Non formal education & 70 & $30.2 \%$ \\
\hline Primary education & 62 & $26.7 \%$ \\
\hline Secondary education & 58 & $25.0 \%$ \\
\hline Tertiary education & 42 & $18.1 \%$ \\
\hline Total & $\mathbf{2 3 2}$ & $\mathbf{1 0 0 \%}$ \\
\hline
\end{tabular}

Table 3: Shows that $70(30.2 \%)$ of women had non-formal education.

Table 4: Respondents Level Of Awareness Of Menopausal Coping Strategies Based On Ages.

\begin{tabular}{|l|l|l|l|}
\hline Ages & High & Low & Total \\
\hline $40-50$ years & $40(17.3 \%)$ & $46(19.5 \%)$ & 86 \\
\hline$\geq 51$ years & $52(22.4 \%)$ & $94(40.5 \%)$ & 146 \\
\hline
\end{tabular}

Table 4: Shows that respondent aged 51 years and above had low level of awareness compared to age range of 40-50 years.

Table 5: Frequency distribution of respondent's level of awareness of exercise as a menopausal coping strategy.

\begin{tabular}{|l|l|l|l|}
\hline Exercise as a coping strategy & High & Low & Total \\
\hline Stair running & $92(39.7 \%)$ & $140(60.3 \%)$ & 232 \\
\hline Brisk walking & $117(50.6 \%)$ & $115(49.4 \%)$ & 232 \\
\hline Running on the spot & $92(39.7 \%)$ & $140(60.3 \%)$ & 232 \\
\hline Sit up & $55(23.7 \%)$ & $177(76.3 \%)$ & 232 \\
\hline Gardening & $126(54.9 \%)$ & $106(45.1 \%)$ & 232 \\
\hline Cycling & $115(49.5 \%)$ & $117(50.5 \%)$ & 232 \\
\hline Swimming & $80(36.7 \%)$ & $152(63.3 \%)$ & 232 \\
\hline
\end{tabular}




\begin{tabular}{|l|l|l|l|}
\hline Dancing & $123(53.0 \%)$ & $109(47.0 \%)$ & 232 \\
\hline Stretching of the body & $78(33.6 \%)$ & $154(66.4 \%)$ & 232 \\
\hline Hiking/Long walk & $94(40.5 \%)$ & $138(59.5 \%)$ & 232 \\
\hline
\end{tabular}

Table 5 shows respondents' level of awareness of exercise as a menopausal coping strategy. Awareness of brisk walking (50.6\%), gardening (54.9\%), cycling (49.5\%), and dancing (53.0\%) as coping strategies were high while sit-up (76.3\%), stretching of the body (66.4\%), swimming (63.3\%), running on the spot and stair running $(60.3 \%)$ were low among respondents.

Table 6: Frequency distribution of respondents` level of awareness of adequate diet as a menopausal coping strategy.

\begin{tabular}{|l|l|l|l|}
\hline Diet as a coping strategy & High & Low & Total \\
\hline $\begin{array}{l}\text { Food rich in calcium such as milk, cheese, } \\
\text { spinach. }\end{array}$ & $123(53.0 \%)$ & $109(47.0 \%)$ & 232 \\
\hline $\begin{array}{l}\text { Carbohydrate rich foods such as rice, yam, garri, } \\
\text { corn }\end{array}$ & $93(40.05 \%)$ & $139(59.95 \%)$ & 232 \\
\hline $\begin{array}{l}\text { Cholesterol-free oil and cold pressed oil such as } \\
\text { soy bean oil, corn oil, wheat germ oil, flax oil }\end{array}$ & $93(40.05 \%)$ & $139(59.95 \%)$ & 232 \\
\hline $\begin{array}{l}\text { Food rich in vitamin A such as butter, milk and } \\
\text { milk products, liver, fish, red oil }\end{array}$ & $104(44.8 \%)$ & $128(55.2 \%)$ & 232 \\
\hline Dark green leafy vegetables such as pumpkin leaf & $126(54.3 \%)$ & $106(45.70 \%)$ & 232 \\
\hline $\begin{array}{l}\text { Fresh fruits such as apple, orange, mango, } \\
\text { banana, berries, tangerine }\end{array}$ & $59(25.25 \%)$ & $173(74.75 \%)$ & 232 \\
\hline Protein rich foods such as beans ,milk, meat, fish & $71(30.4 \%)$ & $161(69.6 \%)$ & 232 \\
\hline Drinking enough water about 6-8 glasses per day & $121(52.15 \%)$ & $111(47.85 \%)$ & 232 \\
\hline $\begin{array}{l}\text { Foods and juice fortified with calcium such as fat- } \\
\text { free yoghurt }\end{array}$ & $78(33.6 \%)$ & $154(66.4 \%)$ & 232 \\
\hline Eat starchy cereals, root tubers everyday & $100(43.1 \%)$ & $132(56.9 \%)$ & 232 \\
\hline
\end{tabular}

Table 6: Shows respondents` level of awareness of adequate diet as a menopausal coping strategy. A total of 126(54.3\%) had high level of awareness of dark green leafy vegetables, $123(53.0 \%)$ food rich in calcium, and drinking 6-8 glasses of water per day as menopausal coping strategies while eating of starchy cereals and tubers (132(56.9\%), $139(59.95 \%)$ for carbohydrates and cholesterol-free oil respectively, $154(66.4 \%)$ for foods and juice fortified with calcium, and $173(74.75 \%)$ for fresh fruits and vegetables were low as menopausal coping strategies in Umuowa community

Table 7: Frequency distribution of respondents` level of awareness of estrogen replacement therapy as a menopausal coping strategy.

\begin{tabular}{|l|l|l|l|}
\hline Estrogen replacement therapy & High & Low & Total \\
\hline Use of vaginal creams & $104(44.55 \%)$ & $128(55.35 \%)$ & 232 \\
\hline $\begin{array}{l}\text { Use of pills such as microgynon and } \\
\text { Lo-femenal }\end{array}$ & $92(39.4 \%)$ & $140(60.6 \%)$ & 232 \\
\hline Use of injections that contain estrogen & $111(47.9 \%)$ & $121(52.1 \%)$ & 232 \\
\hline Daily oral administration of estrogen & $58(25.0 \%)$ & $174(75.0 \%)$ & 232 \\
\hline $\begin{array}{l}\text { Use of natural estrogen obtained from } \\
\text { the urine of pregnant horses }\end{array}$ & $98(42.0 \%)$ & $134(58.0 \%)$ & 232 \\
\hline $\begin{array}{l}\text { Use of natural hormones such as } \\
\text { estrone, estradiol, and estriol, }\end{array}$ & $86(37.05 \%)$ & $146(62.95 \%)$ & 232 \\
\hline $\begin{array}{l}\text { Use of estrogenic substances produced } \\
\text { by plants }\end{array}$ & $83(37.05 \%)$ & $149(62.95 \%)$ & 232 \\
\hline $\begin{array}{l}\text { Use of phytoestrogen herbs such as } \\
\text { black cohosh, and macafem nutrients }\end{array}$ & $74(31.65 \%)$ & $158(68.35 \%)$ & 232 \\
\hline Use of synthetic hormones & $102(43.95 \%)$ & $130(56.05 \%)$ & 232 \\
\hline
\end{tabular}

Table 7: Shows that 104(44.55\%) use vaginal creams, 111(47.9\%) of women use injections that contain estrogen, and 102 (43.95\%) use synthetic hormones. However, there was a corresponding low level of estrogen replacement as a menopausal coping strategy among the women in Umuowa community.

\section{Discussion}

Most healthy women will transit to climacteric phase of reproductive life and eventually post menopausal stage in life (Grady, 2006). Menopausal coping strategies have been deemed as a necessary support for women undergoing menopause(Santoro et al, 2015) and these have been divided into hormonal and nonhormonal coping strategies (Ewuzie, 2007; Nnodum, 2004). The results of this study revealed that age may be a factor in menopausal coping strategies. The mean age of the respondents was 50.4 \pm 0.86 . Women aged 51years and above had low level of awareness (40.5\%) compared to those 40years and above (19.5\%). This finding is in 
consonance with that of Imogie (2002), that age has been implicated in menopausal symptoms and coping styles which may be due to other factors like education and knowledge of the subject matter and physical activities. Furthermore, Ensieh et al (2013) had also stated that management of menopause should first begin with the knowledge that it is a phase in life which women go through as this will enhance their application of these strategies in coping with menopause.

Menopause is a stressful period that may be associated with neuroticism and seeking social support(Bosworth et al, 2003). Shinde (2014) has also noted that women experiencing menopause with psychological problems, if knowledgeable enough, will adopt one or more of these coping strategies to overcome these problems. Yazdkhasti et al (2015) further opined that health education intervention strategy, exercise, healthy diet, stress management, preventing diseases' like osteoporosis are several ways of empowering women to cope with menopause, however, this study clearly shows that the awareness of these coping strategies was indeed low and may extrapolate to the practice of such being also low.

The results further showed that awareness of exercise and hormone replacement therapy (58\% and $62 \%$ respectively), as menopausal coping strategies were generally low in the community and was more among women who had non-formal education (30.2\%). Onuzulike (2007) stated that engaging in regular and moderate exercises could help alleviate the symptoms of menopause. Matsuzaki (2016) further reiterated that women with sufficient understanding of symptoms of menopause are likely to cope better, and even accept hormone replacement therapy as a menopausal coping strategy.

There was also low level of adequate diet( especially fresh fruits $74.75 \%$, and protein rich foods $69.6 \%$ ) as a coping strategy, this is in tandem with findings by Achunine (2007) that women do not eat adequate diet that will help them cope with menopause either due to ignorance or lack of knowledge of how to combine local nutritive foods to meet the required need for their body. Knowledge and awareness are therefore important to understanding menopause and coping with it. We therefore concluded that women in Umuowa community had low level of awareness of exercise, diet, and estrogen replacement as coping strategies for menopause. We recommend that enlightenment campaign and education of women in the community and beyond about these strategies will help ease their lives through menopause stage.

Conflict of interest: Non declared.

\section{References}

[1]. Imogie AO. 2002. Post menopausal health problems and coping mechanisms of women. Nigerian journal of health education. 7(1): 45-55.

[2]. Andrea C. 2014. An overview of menopause: American College of Obstetricians and Gynecologists (2014). ACOG practice bulletin no.141: Management of Menopausal Symptoms. Obstet Gynecol 2014;123:202-16.

[3]. Masters B, Johnson. 2001. Human sexual response. Chicago; unity press

[4]. Wood V. 2001. The plight of the older women. Manchester; Blackwell publishers.

[5]. Michinlay SN. 2004. Selected studies on menopause. Journal of Bio Social Science. 5(5):53-75.

[6]. Onuzulike NM. 2007. Contemporary health matters. Owerri: Con publishers

[7]. Ewuzie MA. 2007. Women and menopause. A paper presented at the annual seminar of Alvan Ladies Association, Owerri, Imo State, Nigeria.

[8]. Nnodum BI. 2004. Facing the inevitable in the life of every woman: the issue of menopause. The queen of peace 1(1):40-42

[9]. Yazdkhasti M, Simbar M, Abdi F. 2015. Empowerment and coping strategies in menopause women: A review. Iran Red Crescent Med. J. 17(3): e18944

[10]. 10. Osinowo HO. 2003. Psychosocial factors associated with perceived psychological health, perception of menopause and sexual satisfaction in menopausal women and controls. : West Afr J Med. Sep;22(3):225-31. PMID: 14696946 [PubMed - indexed for Medline].

[11]. Onuzulike NM. 2004. Feminity and menopause: strategies for coping. Nurses Guild Mirror. 1(1) 22-24.

[12]. Grady D. 2006. Clinical practice: Management of menopausal symptoms. N Engl J Med. 355(22) 2338-2347.

[13]. Soules MR. 2005. Development of the staging system for menopause transition: a work in progress. Menopause 12:117-120.

[14]. Ande AB, Omu OP, Olagbuji NB. 2011. Features and perceptions of menopausal women in Benin City, Nigeria. Ann Afr Med, 10(4): 300-304.

[15]. Nkwo P, Onah H. 2008. Positive attitude to Menopause and improved quality of life among igbo women in Nigeria. Int $\mathrm{j}$ Gynecol. Obstet, 103(1) 71-72.

[16]. Santoro N, Epperson NC, Mathews SB. 2015. Menopausal symptoms and their treatment. Endocrinol Metab Clin North Am. 44(3): 497-515.

[17]. Ejifugha AU. 2005. Fundamentals of research in health education. Owerri. Luso publishers.

[18]. Ensieh N, Nayereh KD, Ahmad EA, Akbar H, Soheila D. 2013. Knowledge and attitude toward menopause phenomenon among women aged 40-45 years. J Educ Health Promot. 2013; 2 : 25.

[19]. Matsuzaki K, Uemura H, Yasui T. 2016. Differences in coping with menopausal symptoms in nurses and general workers in Japan. Maturitas 86: 45-52.

[20]. Achunine S. 2007. Coping with menopause (2). The Leader Newspaper Vol 2; 1-5

[21]. Bosworth HB, Bastian LA, Rimer BK, Siegler IC. 2003. Coping styles and personality domains related to menopausal stress. Convenience direct.com/Science/J Vol 13 (1): 32-38.

[22]. Shinde MB. 2014. Psychological problems and coping strategies adopted by post menopausal women. International journal of Science and Research (IJSR) 3(2): 293-300. 